\title{
Correlation Between Poor Prognosis and Lower TPPP Gene Expression in Hepatocellular Carcinoma
}

\author{
YOSHIKUNI INOKAWA ${ }^{1,2}$, FUMINORI SONOHARA ${ }^{1,2}$, MITSURO KANDA $^{1}$, MASAMICHI HAYASHI $^{1}$, \\ YOKO NISHIKAWA ${ }^{1}$, HIROYUKI SUGIMOTO ${ }^{1}$, YASUHIRO KODERA ${ }^{1}$ and SHUJI NOMOTO ${ }^{1,2}$ \\ ${ }^{1}$ Gastroenterological Surgery (Surgery II), Nagoya University Graduate School of Medicine, Nagoya, Japan; \\ ${ }^{2}$ Department of Surgery, Aichi Gakuin University School of Dentistry, Nagoya, Japan
}

\begin{abstract}
Background/Aim: Post-resection recurrence of hepatocellular carcinoma (HCC) tends to derive from multicentric origins, which indicates that the background liver microenvironment affects carcinogenesis. Materials and Methods: We obtained control liver samples [super normal $(S N)]$ from 11 patients with secondary metastatic liver malignancies and used expression and methylation arrays to compare them with non-cancerous liver tissue from a patient with typical HCC with chronic hepatitis $C$ (corresponding normal $(C N)]$. Results: The expression array showed that gene expression of tubulin polymerization-promoting protein (TPPP) was lower in CN compared with SN. The methylation array showed a greater TPPP methylation index for $C N$ than for $S N$. Transcripts of TPPP differed significantly among $S N(n=11)$, $C N(n=179)$, and tumor tissue of HCC $(n=179)$ (median of 116 , 4.60 , and 2.63, respectively, $p<0.001$ ). Multivariate analysis showed lower TPPP expression in tumor than in normal tissue (ratio $<0.3, n=57$ ) to independently predict poor overall survival $(p=0.031)$. Conclusion: Significantly lower TPPP expression was found in HCC and CN tissue compared to SN and indicated poor prognosis.
\end{abstract}

Hepatocellular carcinoma (HCC) is the sixth most common cancer and the third most frequent cause of cancer-related death worldwide (1), and its incidence is steadily rising. Despite therapeutic options such as hepatic resection (2), liver transplantation (3), radiofrequency ablation (4), transcatheter arterial chemoembolization (5), and sorafenib (6), the prognosis for patients with advanced HCC remains poor $(7,8)$. The mechanisms of hepatocarcinogenesis thus urgently need clarification (9).

Correspondence to: Shuji Nomoto, Department of Surgery, Aichi Gakuin University School of Dentistry, Nagoya 464-8651, Japan. Tel: +81 527592167, Fax: +81 527592107, e-mail: snomoto@dpc.agu.ac.jp

Key Words: Background liver, hepatocellular carcinoma, methylation, multi-array analysis, TPPP/p25.
Up to $70 \%$ of patients develop tumor recurrence within 5 years of resection for HCC (2), mostly in the remnant liver (10). Recurrence in remnant liver is considered to reflect intrahepatic metastasis (IM) or multicentric occurrence (MO) (11). We previously reported clonal analyses that showed recurrent HCC genotypes, mutations of the mitochondrial genome (12), or patterns of promoter hypermethylation in several tumor suppressor genes in tumor cells (13), and found MO to be a more common source of recurrence than IM. This suggests that the background liver microenvironment has a larger role in hepatocarcinogenesis than does the primary tumor.

We developed a multi-array analysis from expression and methylation arrays of background liver (14), which found tubulin polymerization-promoting protein $(T P P P)$ to be an HCC-related gene in parenchymal tissue that surrounds $\mathrm{HCC}$ tumors. Although TPPP (also called p25) was found to be a brain-specific protein that binds to tubulin and microtubules (15), to our knowledge, its role in HCC has not been studied. We, therefore, investigated its expression, methylation and prognostic effect in patients who underwent liver resection for HCC.

\section{Materials and Methods}

Sample collection and DNA preparation. Control samples, termed super normal (SN) liver, were obtained from normal liver tissues of 11 patients with metastatic secondary malignancies to the liver who underwent liver resection at our Department. Their primary diseases included five with colorectal cancer, two with gastrointestinal stromal tumor, and one each with gastric cancer, esophageal cancer, cervical cancer, and tongue cancer. We compared these samples with a corresponding normal tissue specimen from a typical case of HCC that was generated from chronic hepatitis $\mathrm{C}(\mathrm{CN})$. This latter patient was a 58-year-old man with liver cirrhosis who had undergone a liver resection from which the $\mathrm{CN}$ tissue was obtained; his recurrence presented 3 years after resection of the primary lesion. DNA and RNA were extracted from the $\mathrm{SN}$ and $\mathrm{CN}$ tissues. In making pathological slides to extract DNA and RNA, we carefully confirmed that the corresponding normal tissue had no cancer tissues by pathological diagnoses. Expression profiling and 
methylation arrays were used to compare $\mathrm{SN}$ and $\mathrm{CN}$. We identified genes that differed in expression and rate of methylation.

We also collected primary HCC tissues and corresponding noncancerous tissues taken during liver resection at Nagoya University Hospital between 1994 and 2008 from 179 HCC patients (mean age $=62.2 \pm 9.9$ years; range $=21-84$ years; 152 men and 27 women). The median follow-up period was 67.6 months (range $=0.3$ 208.9 months). All patients gave written informed consent, as required by the Institutional Review Board. All these tissues were diagnosed histologically as HCC. Samples were frozen immediately in liquid nitrogen and stored at $-80^{\circ} \mathrm{C}$ until needed. Genomic DNA was taken from tissue samples by proteinase $\mathrm{K}$ digestion, followed by phenol/chloroform extraction.

RNA isolation and microarray procedures. Total RNA was extracted from the $\mathrm{SN}$ and $\mathrm{CN}$ samples using the Qiagen miRNeasy Mini kit (Toronto, ON, Canada). RNA quality was assessed as an RNA integrity number of $\geq 8$ using an Agilent 2100 Bioanalyzer (Agilent, Mississauga, ON, Canada).To eliminate personal background, total RNA of 11 SN samples were mixed. Total RNA was labeled with cyanine-3 dye using a Quick Amp Labeling Kit (Agilent) and hybridized to Agilent Whole Human Genome $(4 \times 44 \mathrm{~K})$ microarrays for $17 \mathrm{~h}$ in a rotating SciGene model 700 oven (Sunnyvale, CA, USA). Arrays were scanned by a DNA Microarray Scanner (Agilent). Data were extracted using Feature Extraction Software 10.5.1.1 (Agilent) and statistically analyzed by default settings on GeneSpring GX 11.0.1 software (Agilent) (16).

Methylation array platform. The Illumina Infinium Human Methylation 27 Bead Chip protocol uses $500 \mathrm{ng}$ to $1 \mu \mathrm{g}$ of bisulfiteconverted DNA (17). Methylation array analysis was performed as described previously $(18,19)$.

Methylation-specific PCR (MSP). DNA from HCC cell lines, 179 of resected HCC tissues (HTs) and adjacent normal tissues (NTs) were subject to bisulfite treatment. Briefly, $2 \mu \mathrm{g}$ of DNA was denatured by $\mathrm{NaOH}$ and modified by sodium bisulfite. DNA samples were then purified using Wizard purification resin (Promega Corp., Madison, WI, USA), treated with $\mathrm{NaOH}$, precipitated with ethanol and resuspended in water. Primer pairs were used to detect methylation (sense, 5'-GGT AGA GGT TTC GGT GCG TT-3'; antisense, 5'-ACG AAA CTC TCC AAC CGC CG-3'; 198-bp product) and non-methylation (sense, 5'-GTG GGG GTG GGG TTG TTA AT-3'; antisense, 5'-AAC ATC CAA CAC CCA CCC AA-3'; 59-bp product) of the TPPP promoter region near exon 1. MSP amplification was performed as follows: denaturation at $94^{\circ} \mathrm{C}$ for $3 \mathrm{~min}$ followed by 38 cycles at $94^{\circ} \mathrm{C}$ for $10 \mathrm{~s}, 60^{\circ} \mathrm{C}$ for $8 \mathrm{~s}$ and $72^{\circ} \mathrm{C}$ for $6 \mathrm{~s}$. Unmethylated-specific PCR (UNMSP) amplification was performed as follows: denaturation at $94^{\circ} \mathrm{C}$ for 3 min followed by 42 cycles at $94^{\circ} \mathrm{C}$ for $8 \mathrm{~s}, 62^{\circ} \mathrm{C}$ for $5 \mathrm{~s}$ and $72^{\circ} \mathrm{C}$ for $3 \mathrm{~s}$. PCR products were loaded directly onto $3 \%$ agarose gels, stained with ethidium bromide and visualized under UV light.

Reverse transcription-polymerase chain reaction (RT-PCR). TPPP mRNA expression was analyzed by semi-quantitative RT-PCR and real-time RT-PCR. Total RNA $(10 \mu \mathrm{g})$ isolated from nine HCC cell lines, primary HTs and NTs were used to generate cDNAs, which were then amplified by PCR using primers for TPPP (sense, 5'-AGG ACT GCC AGG TGA TCG AC-3' in exon 3); antisense 5'-CTT GCC CTC GAT GAG CCT GT-3' in exon 4), which amplified a 200 bp product. PCR was performed using the following parameters: initial denaturation at $94^{\circ} \mathrm{C}$ for $3 \mathrm{~min}$, followed by 36 cycles of $94^{\circ} \mathrm{C}$ for 10 $\mathrm{s}, 60^{\circ} \mathrm{C}$ for $8 \mathrm{~s}$ and $72^{\circ} \mathrm{C}$ for $6 \mathrm{~s}$. RT-PCR of $\beta$-actin was performed to confirm equal amounts of cDNA template in each amplification. Each PCR product was loaded directly onto $3 \%$ agarose gels, stained with ethidium bromide and visualized under UV light.

5-Aza-2'-deoxycytidine (5-aza-dC) treatment. HCC cell lines were treated with $1 \mu \mathrm{M}$ 5-aza-dC (Sigma-Aldrich, St. Louis, MO, USA) to inhibit DNA methylation. Cells $\left(1.5 \times 10^{6}\right)$ were cultured for 6 days with medium changes on days 1,3 and 5 . On day 6 , cells were harvested, RNA was extracted and RT-PCR was performed as described above.

Real-time quantitative RT-PCR (qRT-PCR). qRT-PCR was performed using a SYBR Green PCR Core Reagents kit (Applied Biosystems, Foster City, CA, USA) under the following conditions: one cycle at $95^{\circ} \mathrm{C}$ for $10 \mathrm{~s}$, followed by 40 cycles at $95^{\circ} \mathrm{C}$ for $5 \mathrm{~s}$ and at $60^{\circ} \mathrm{C}$ for $30 \mathrm{~s}$. SYBR Green emission was detected in real time using a StepOnePlus ${ }^{\mathrm{TM}}$ Real-Time PCR Systems (Applied Biosystems, Foster City, CA, USA). The primers used for qRT-PCR were the same as those described above for RT-PCR. Samples were standardized to glyceraldehyde 3-phosphate dehydrogenase $(G A P D H)$. qRT-PCR was performed at least three times, including negative controls without a template. TPPP expression was decided as the value of $T P P P \times 10^{3} / G A P D H$ in each sample.

Statistical analysis. Continuous variables are expressed as medians (range). Comparisons were made using the Mann-Whitney $U$-test. Categorical variables were compared using $\chi^{2}$ tests or Fisher's exact tests, where appropriate. Overall survival (OS) rates were analyzed by Kaplan-Meier and log-rank tests. All statistical analyses were performed on JMP software version 9.0.2 (SAS International Inc., Cary, NC, USA). A value of $p<0.05$ was considered significant.

\section{Results}

Expression profiling and methylation array analysis. To identify novel tumor-related genes in background normal liver, we first looked for genes with lower expression in $\mathrm{CN}$ compared to $\mathrm{SN}$ tissue. Expression array analysis revealed that in $\mathrm{CN}$, expression of TPPP, which is involved in neuropeptide metabolism, was strongly down-regulated (2.236-fold $\log 2$ ratio) compared to SN (Table I).

Methylation array analysis showed continuous $\beta$ values of 0.731 for $\mathrm{CN}$ tissue versus 0.384 for $\mathrm{SN}$ tissue, indicating a high degree of methylation in the $\mathrm{CN}$ sample from the hepatitis $\mathrm{C}$ virus $(\mathrm{HCV})^{+}$patient (Table II). This implies that a mechanism of TPPP down-regulation is through hypermethylation of its promoter region in background liver tissue.

Methylation status of HCC cell lines. We next investigated the methylation status of TPPP in nine HCC cell lines, using primers for methylated and unmethylated TPPP. For methylation-specific (MSP) analysis, bands of appropriate size were observed for HLE, HuH2, HuH7 and SK-Hep1 cell lines, whereas appropriate bands were identified in all cell 
Table I. Expression array analysis of tubulin polymerization-promoting protein (TPPP) in super normal (SN) and corresponding normal (CN) liver tissues.

\begin{tabular}{lccccccc}
\hline Probe set ID & Gene symbol & Log2 ratio & SN signal & Detection & CN signal & Detection & Chromosomal location \\
\hline A_23_P117464 & TPPP & -2.236 & 357.4 & Present & 192.6 & Present & Chr5p15.3 \\
\hline
\end{tabular}

lines for unmethylated TPPP (Figure 1a). These results indicate partial methylation of TPPP in HLE, HuH2, HuH7 and SK-Hep1 and no methylation in HepG2, Hep3B, HLF, $\mathrm{HuH} 1$ and PLC/PRF/5 cells.

Inhibitory effect of methylation on TPPP expression in HCC cell lines. To confirm that TPPP expression was silenced by promoter hypermethylation, we analyzed TPPP mRNA expression in nine HCC cell lines before and after treatment with the DNA methylation-inhibitory agent 5-aza-dC; TPPP expression was clearly reactivated after 5-aza-dC treatment in three cell lines (HLE, HLF and SK-Hep1), as shown by semi-quantitative RT-PCR (Figure 1b).

MSP and non-MSP of SN, normal and tumor tissues from $p w$ $H C C$. We next assessed TPPP promoter hypermethylation in SN, normal and tumor tissues from 179 patients with HCC. Overall, $28.4 \%(51 / 179)$ of tumor samples displayed TPPP promoter hypermethylation compared with $9.4 \%$ (17/179) of normal samples (Table III). SN tissues showed no methylation in all 11 cases (Figure 2a). Thus, hypermethylation of TPPP was significantly more frequent in tumor tissues than $\mathrm{CN}$ tissues $(p<0.001)$ and $\mathrm{SN}(p=0.038)$. Although SN and CN were not significant different $(p=0.602), \mathrm{CN}$ tended to be more methylated than SN (Table III). Four representative cases of methylated and unmethylated status are shown in Figure $2 \mathrm{~b}$.

qRT-PCR of SN and CN tissue of HCC cases. Overall, TPPP expression (relative to GAPDH) was significantly lower in CN samples $(n=179)$ than in SN tissues $(n=11)$, with median $T P P P \times 10^{3} / G A P D H$ ratios for $\mathrm{SN}$ of $116($ range=31.0-348) $v s$. CN of 4.60 (range=0.500-64.3) $(p<0.001)$, and lower still in tumor tissues (median $T P P P \times 10^{3} / G A P D H$ ratio $=2.63$, range $=0.0240-300)$ than in $\mathrm{CN}$ tissues $(p<0.001)$ (Figure 3 ). The TPPP expression index was calculated as the tumor tissue expression level divided by the expression in adjacent normal tissue. The methylation status evaluated by MSP and expression indices did not show any statistically significant correlation (data not shown).

Correlation between down-regulation of TPPP and HCC clinicopathological characteristics. A lower TPPP expression index was significantly correlated with poorly differentiated HCC $(p=0.038)$ and high alpha-feto-protein
(AFP) level ( $p=0.012$ ) (Table IV). The group of patients with $T P P P$ expression indices $<1.0(\mathrm{n}=121)$ had worse OS after surgery than the group with $T P P P$ expression indices $\geq 1.0$ $(\mathrm{n}=58)(p=0.047$; Figure $4 \mathrm{a})$. Moreover, the 57 patients with TPPP expression indices $<0.3$ had significantly worse prognoses than other patients $(p<0.001$; Figure $4 \mathrm{~b})$.

Univariate analysis of OS identified significant correlations with viral infection (HCV vs. other) $(p=0.032)$, liver cirrhosis $(p=0.036)$, multiple tumors $(p=0.016)$, vascular invasion $(p<0.001)$, pathological type (well/moderately differentiated $v s$. poorly differentiated; $p=0.036)$, AFP level ( $\geq 20 \mathrm{ng} / \mathrm{ml} ; p=0.001)$, advanced tumor stage (Japan Stage I-II $v s$. III-IV; $p=0.028)$ and TPPP expression index $<0.3(p<0.001)$ (Table V).

Multivariate analysis showed OS to be significantly correlated with HCV infection $(p<0.001)$, vascular invasion $(p<0.001)$, higher AFP level $(p=0.038)$ and TPPP expression index $<0.3(p=0.031)$ (Table V).

\section{Discussion}

Usually, HCC develops within an established background of chronic liver disease (20). The high incidence of intrahepatic recurrence is a major problem in HCC therapy $(10,21)$. HCC has a peculiar progression pattern; unlike most other malignancies, most patients with HCC have lesions only in their livers without metastasis to other organs (22). The background liver environment in $\mathrm{HCC}$, thus, merits intense investigation.

We previously reported that HCC recurrence after liver surgery is mainly MO not IM $(12,13)$, which indicates that recurrent lesions derive from oncogenic activities of background liver parenchyma rather than primary lesions. This implies that background liver tissue is a greater factor in HCC than is tumor tissue. We developed a multi-array analysis to investigate gene expression in these tissues (14).

Here, our multi-array analysis detected the gene for TPPP, identified as a brain-specific protein (also called p25) $(15,23)$. Only a few reports have been published regarding its effect in carcinogenesis (24-26), and to our knowledge, no studies have been published of its role in HCC or liver tissue. However, GeneCards indicates that among internal organs, TPPP is strongly expressed in liver tissue (27), which concurred with our array analysis and RT-PCR showing TPPP mRNA to be 
a

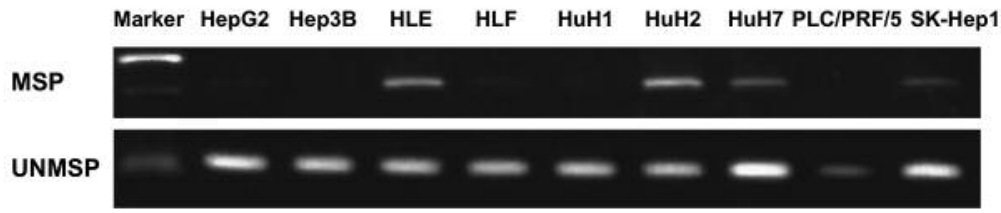

b

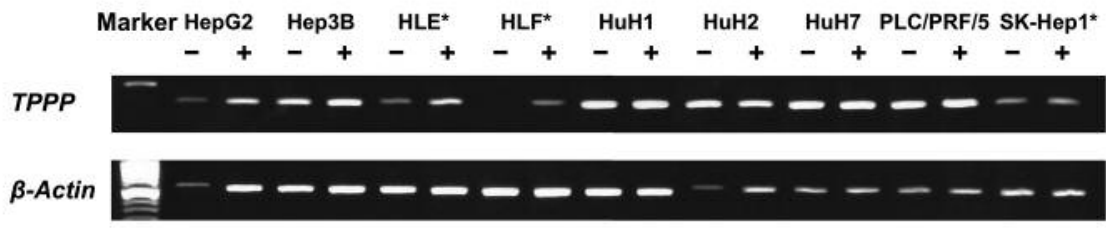

Figure 1. Results of polymerase chain reaction for nine hepatocellular carcinoma (HCC) cell lines. a: polymerase chain reaction (PCR) for methylation-specific (MSP) and unmethylated (UNMSP) tubulin polymerization-promoting protein (TPPP) gene. The HLE, HuH2, HuH7 and SKHep1 cell lines were $M S P^{+}$; but all cell lines were UNMSP+. $b$ : Semi-quantitative reverse transcription PCR revealed reactivation of TPPP $m R N A$ expression in three out of nine HCC cell lines (HLE, HLF and SK-Hep1; shown with asterisks) after treatment with the DNA methylation-inhibitory agent agent 5-aza-2'-deoxycytidine.

a

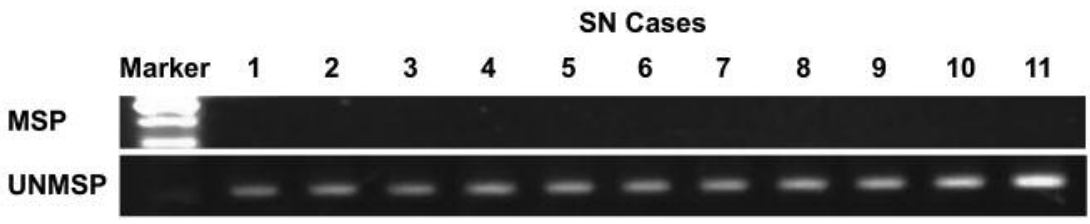

b

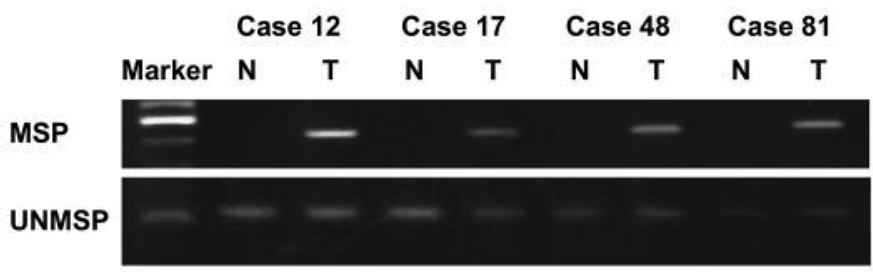

Figure 2. Results of polymerase chain reaction for methylation-specific (MSP) and unmethylated (UNMSP) tubulin polymerization-promoting protein (TPPP) gene in super normal (SN) cases (a) and hepatocellular carcinoma cases (b). a: SN tissues showed no methylation in all 11 cases. b: Representative four cases show hypermethylation of the promoter region of TPPP gene in tumor tissues, but no methylation in normal tissues.

highly expressed in SN liver parenchyma, significantly downregulated in $\mathrm{CN}$ tissues and even further down-regulated in tumor tissues. We consider that decreased TPPP expression is important in hepatocarcinogenesis, and its down-regulation might reflect promoter methylation.

Schofield et al. investigated TPPP and showed that its overexpression reduces, and its knockdown increases, proliferation in the U2OS cell line (28). They studied the effect of TPPP on the cell cycle and found it to inhibit $G_{1} / S$ phase transition. Lehotzky et al. also showed that siRNA knockdown of TPPP inhibited differentiation and promoted proliferation, which implies an important role for TPPP in oligodendrogenesis (29). An immunohistochemical study showed TPPP expression in non-neoplastic oligodendrocytes, but not in oligodendroglioma cells (24). Therefore, TPPP might act as a tumor suppressor in some malignancies by delaying the cell cycle and inhibiting proliferation, which would accord with our results.

In the future, liver parenchyma specimens taken from percutaneous liver biopsy for patients with chronic hepatitis or liver cirrhosis could predict the presence of HCC by evaluating TPPP expression. Furthermore, decreased TPPP expression in peripheral blood samples might help detect early-stage HCC in patients with chronic liver disease.

A possible limitation of this study is our use of only one $\mathrm{CN}$ sample for array analysis whereas we mixed $11 \mathrm{SN}$ samples; however, we considered that we should not mix multiple cases in order to find an altered molecule in $\mathrm{CN}$ because a specific 


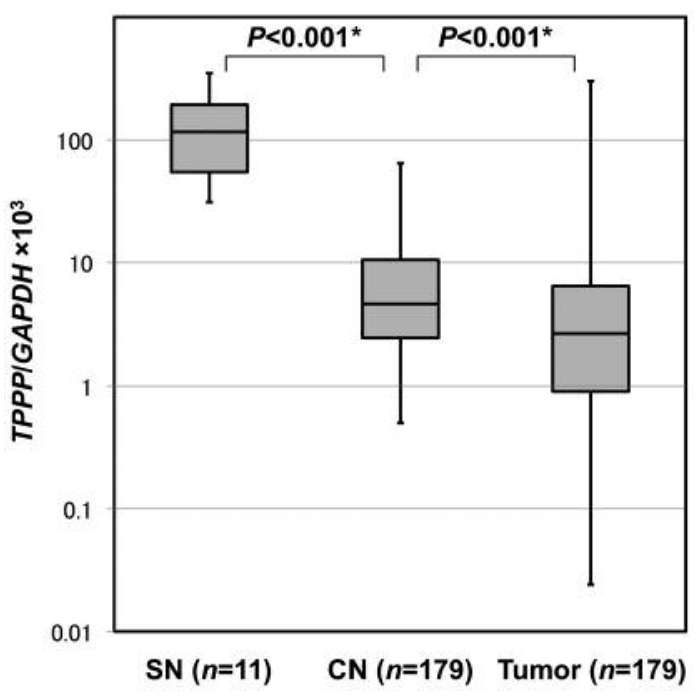

Figure 3. Result of real-time quantitative reverse transcriptionpolymerase chain reaction. Expression levels of tubulin polymerizationpromoting protein (TPPP) $m R N A$, divided by glyceraldehyde 3phosphate dehydrogenase (GAPDH) level, in specimens of super normal $(S N, n=11)$ without hepatocellular carcinoma (HCC), corresponding normal (CN, $n=179)$ of HCC and tumor tissues ( $n=179)$ of HCC determined by quantitative RT-PCR. TPPP expression was significantly lower in CN tissues than SN samples; with median TPPP $\times 10^{3} / G A P D H$ ratios for $S N$ of 116 (range $=31.0-348)$ vs. $C N$ of 4.60 (range $=0.5-64.3$ ) $(p<0.001)$; and lower still in tumor tissues (median TPPP $\times 10^{3} /$ GAPDH ratio $=2.63$; range $\left.=0.0240-300 ; p<0.001\right)$.

Table II. Methylation array analysis of tubulin polymerizationpromoting protein $(T P P P)$ in super normal $(S N)$ and corresponding normal $(C N)$ liver tissues.

\begin{tabular}{lccc}
\hline Gene symbol & Sample & $\begin{array}{c}\text { Methylation } \\
\text { value (0-1) }\end{array}$ & $\begin{array}{c}\text { Chromosomal } \\
\text { location }\end{array}$ \\
\hline TPPP & SN & 0.384 & Chr5p15.3 \\
& CN & 0.731 & \\
\hline
\end{tabular}

abnormality is unlikely to exist in all cases. Conversely, in order to estimate the SN samples as controls without aberrance, we mixed 11 samples of normal liver tissue to erase tissue idiosyncrasy. We picked up the TPPP gene by array analysis, and then verified the result by specimens from 179 patients with $\mathrm{HCC}$, which indicates that our result is widely applicable. As another limitation, we found no statistically significant relationship between promoter methylation and TPPP expression. However, TPPP transcripts were significantly lower among $\mathrm{CN}$ compared to $\mathrm{SN}$, and among tumor tissues compared to $\mathrm{CN}$ (Figure 3), correspondingly, more frequent methylations were observed among $\mathrm{CN}(9.4 \%)$ compared to
Table III. Result of methylation-specific polymerase chain reaction (MSP) for super normal (SN), corresponding normal (CN) and tumorous liver tissues.

\begin{tabular}{lrrr}
\hline MSP & SN & CN & Tumor \\
\hline+ & 0 & 17 & 51 \\
- & 11 & 162 & 128 \\
\hline
\end{tabular}

SN vs. CN: $p=0.6028$; SN vs. tumor: $p=0.0381 ; \mathrm{CN} v s$. tumor: $p<0.001$.

Table IV. Correlation between tubulin polymerization-promoting protein $(T P P P)$ expression indices and clinicopathological characteristics in 179 patients with hepatocellular carcinoma.

\begin{tabular}{|c|c|c|c|}
\hline Characteristic & $\mathrm{N}$ & $\begin{array}{c}\text { Median expression } \\
\text { index }\end{array}$ & $p$-Value \\
\hline \multicolumn{4}{|l|}{ Age (years) } \\
\hline$\geq 65 /<65$ & $85 / 94$ & $0.433 / 0.584$ & 0.252 \\
\hline \multicolumn{4}{|l|}{ Gender } \\
\hline Male/female & $152 / 27$ & $0.492 / 0.614$ & 0.376 \\
\hline \multicolumn{4}{|l|}{$\mathrm{HCV}$} \\
\hline$+/-$ & $112 / 57$ & $0.566 / 0.425$ & 0.154 \\
\hline \multicolumn{4}{|l|}{ HBV } \\
\hline$+/-$ & $40 / 129$ & $0.365 / 0.560$ & 0.120 \\
\hline \multicolumn{4}{|l|}{ Liver cirrhosis } \\
\hline$+/-$ & $51 / 55$ & $0.497 / 0.666$ & 0.268 \\
\hline \multicolumn{4}{|l|}{ Tumor size } \\
\hline$\geq 5 \mathrm{~cm} /<5 \mathrm{~cm}$ & $61 / 94$ & $0.373 / 0.595$ & 0.221 \\
\hline \multicolumn{4}{|l|}{ Tumor number } \\
\hline Solitary/multiple & $109 / 50$ & $0.614 / 0.368$ & 0.071 \\
\hline \multicolumn{4}{|l|}{ Formation of capsule } \\
\hline$+/-$ & $121 / 42$ & $0.544 / 0.403$ & 0.460 \\
\hline \multicolumn{4}{|l|}{ Growth form } \\
\hline Expansive/infiltrative & $134 / 21$ & $0.539 / 0.338$ & 0.154 \\
\hline \multicolumn{4}{|l|}{ Serosal infiltration } \\
\hline$+/-$ & $31 / 98$ & $0.360 / 0.472$ & 0.560 \\
\hline & Vascular invasion & $0.359 / 0.571$ & 0.056 \\
\hline \multicolumn{4}{|l|}{ Differentiation } \\
\hline Well/other & $33 / 123$ & $0.457 / 0.433$ & 0.835 \\
\hline Well, moderate/poor & $146 / 10$ & $0.525 / 0.263$ & 0.038 \\
\hline \multicolumn{4}{|l|}{$\operatorname{AFP}(\mathrm{ng} / \mathrm{ml})$} \\
\hline$\geq 20 /<20$ & $88 / 78$ & $0.420 / 0.676$ & 0.012 \\
\hline \multicolumn{4}{|l|}{ Japan Stage } \\
\hline I-II/III-IV & $93 / 65$ & $0.363 / 0.571$ & 0.080 \\
\hline
\end{tabular}

AFP, Alpha-fetoprotein; $\mathrm{HBV}$, hepatitis B virus; $\mathrm{HCV}$, hepatitis $\mathrm{C}$ virus. The expression index $\left[\left(T P P P_{\text {tumor }}\right) \times\left(G A P D H_{\text {normal }}\right) /\left(T P P P_{\text {normal }}\right) \times\right.$ $\left.\left(G A P D H_{\text {tumor }}\right)\right]$ was calculated for all 179 patients.

SN (0\%), and among tumor tissues (28.4\%) compared to CN (Table III). Thus, we assume that promoter methylation in TPPP is one of the mechanisms of down-regulation of this gene although it is not an exclusive means of regulation of mRNA expression. 

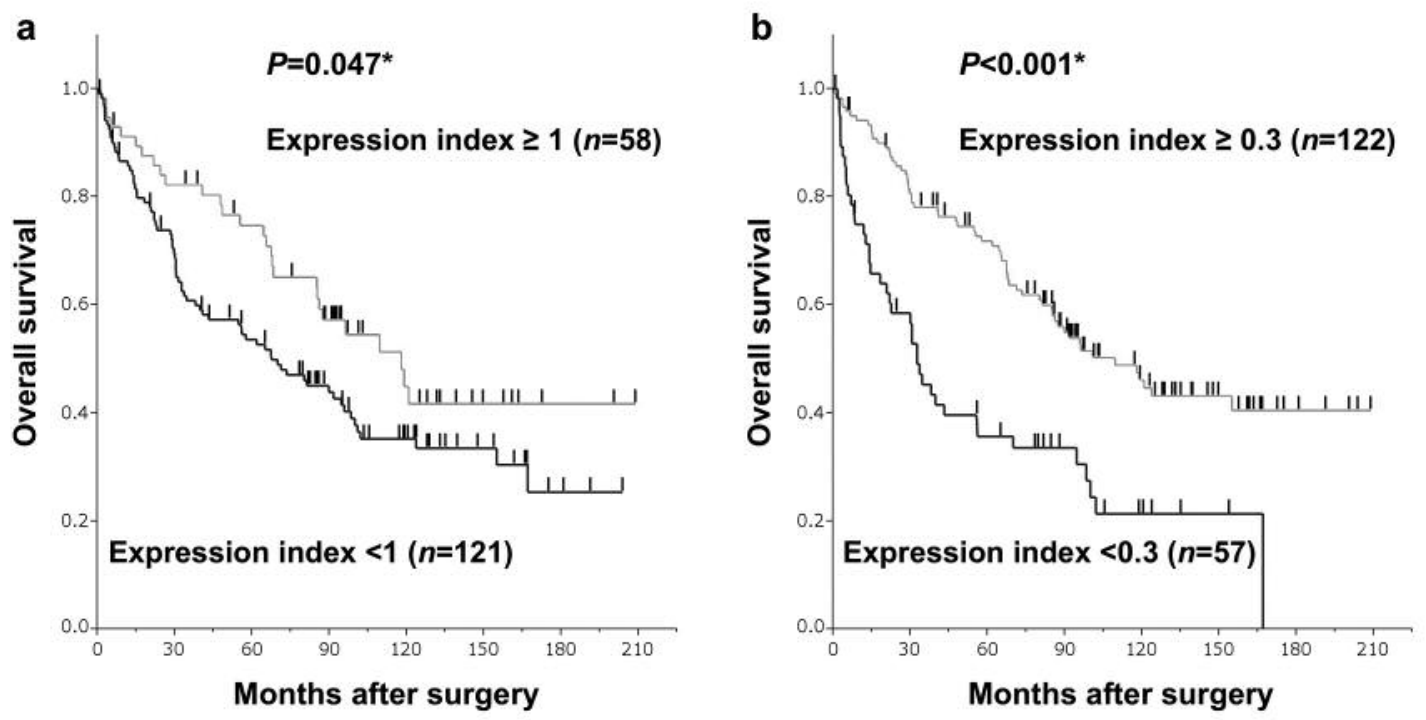

Figure 4. Overall survival rates of patients with hepatocellular carcinoma stratified by expression of tubulin polymerization-promoting protein (TPPP) mRNA. a: We classified the 179 cases according to whether TPPP expression index was higher $(n=58)$ or lower $(n=121)$ than 1.0. The TPPP expression index was calculated as [tumor tissue TPPP expression]/[adjacent normal tissue TPPP expression]. A log-rank test showed significant differences in overall survival rates $(p=0.047) . b$ : The 57 cases with very low TPPP expression indices $(<0.3)$ had significantly worse prognoses than other patients $(p<0.001)$.

Table V. Univariate and multivariate analyses of overall survival.

\begin{tabular}{|c|c|c|c|c|c|c|c|c|}
\hline & & \multirow[b]{2}{*}{$\mathrm{N}$} & \multicolumn{3}{|c|}{ Univariate analysis } & \multicolumn{3}{|c|}{ Multivariate analysis } \\
\hline & & & $\mathrm{HR}$ & $95 \% \mathrm{CI}$ & $p$-Value & HR & $95 \% \mathrm{CI}$ & $p$-Value \\
\hline \multirow[t]{2}{*}{$\mathrm{HCV}$} & + & 112 & 1.66 & $1.04-2.74$ & 0.032 & 3.27 & $1.68-7.02$ & $<0.001$ \\
\hline & - & 57 & 1 & & & & & \\
\hline \multirow[t]{2}{*}{ Liver cirrhosis } & + & 51 & 1.69 & $1.03-2.79$ & 0.036 & 1.58 & $0.892-2.86$ & 0.115 \\
\hline & - & 55 & 1 & & & & & \\
\hline \multirow[t]{2}{*}{ Tumor number } & Solitary & 109 & 1 & & & & & \\
\hline & Multiple & 50 & 1.72 & $1.10-2.64$ & 0.016 & 1.08 & $0.619-1.86$ & 0.763 \\
\hline \multirow[t]{2}{*}{ Vascular invasion } & + & 42 & 2.54 & $1.59-3.96$ & $<0.001$ & 4.35 & $2.31-7.99$ & $<0.001$ \\
\hline & - & 115 & 1 & & & & & \\
\hline \multirow[t]{2}{*}{ Differentiation } & Well, moderate & 146 & 1 & & & & & \\
\hline & poor & 10 & 2.39 & $1.06-4.67$ & 0.036 & 1.7 & $0.550-4.36$ & 0.327 \\
\hline \multirow[t]{2}{*}{$\operatorname{AFP}(\mathrm{ng} / \mathrm{ml})$} & $\geq 20$ & 88 & 2 & $1.30-3.15$ & 0.001 & 1.84 & $1.03-3.37$ & 0.038 \\
\hline & $<20$ & 78 & 1 & & & & & \\
\hline \multirow[t]{2}{*}{ Japan Stage } & I-II & 93 & 1 & & & & & \\
\hline & III-IV & 65 & 1.61 & $1.05-2.47$ & 0.028 & & & \\
\hline \multirow[t]{2}{*}{ Index } & $\geq 1$ & 58 & 1 & & & & & \\
\hline & $<1$ & 121 & 1.53 & $0.990-2.45$ & 0.055 & & & \\
\hline \multirow[t]{2}{*}{ Index } & $\geq 0.3$ & 122 & 1 & & & & & \\
\hline & $<0.3$ & 57 & 2.49 & $1.64-3.76$ & $<0.001$ & 1.86 & $1.06-3.20$ & 0.031 \\
\hline
\end{tabular}

AFP, Alpha-fetoprotein; CI, confidence interval; HCV, hepatitis $\mathrm{C}$ virus; HR, hazard ratio. Index: Expression index $\left[\left(T P P P_{\text {tumor }}\right) \times\right.$ $\left.\left(G A P D H_{\text {normal }}\right) /\left(T P P P_{\text {normal }}\right) \times\left(G A P D H_{\text {tumor }}\right)\right]$.

In conclusion, $T P P P$ expression in HCC background liver and tumor tissue is significantly less than in liver tissue of patients without HCC. These results imply that TPPP is a tumor-suppressor gene for $\mathrm{HCC}$ when detected in background liver, and confirm the efficacy of multi-array analysis of HCC background liver. 


\section{Acknowledgements}

This work was supported by the Japan Society for the Promotion of Science (JSPS) KAKENHI Grant-in-Aid for Scientific Research (C) Number 25461979.

\section{References}

1 Ferlay J, Shin HR, Bray F, Forman D, Mathers C and Parkin DM: Estimates of worldwide burden of cancer in 2008: GLOBOCAN 2008. Int J Cancer 127: 2893-2917, 2010.

2 Llovet JM, Burroughs A and Bruix J: Hepatocellular carcinoma. Lancet 362: 1907-1917, 2003.

3 Clavien PA, Lesurtel M, Bossuyt PM, Gores GJ, Langer B and Perrier A: Recommendations for liver transplantation for hepatocellular carcinoma: an international consensus conference report. Lancet Oncol 13: e11-22, 2012.

4 Tateishi R, Shiina S, Teratani T, Obi S, Sato S, Koike Y, Fujishima T, Yoshida H, Kawabe T and Omata M: Percutaneous radiofrequency ablation for hepatocellular carcinoma - An analysis of 1000 cases. Cancer 103: 1201-1209, 2005.

5 Takayasu K, Arii S, Ikai I, Omata M, Okita K, Ichida T, Matsuyama Y, Nakanuma Y, Kojiro M, Makuuchi M and Yamaoka Y, Liver Canc Study Grp J: Prospective cohort study of transarterial chemoembolization for unresectable hepatocellular carcinoma in 8510 patients. Gastroenterology 131: 461-469, 2006.

6 Abou-Alfa GK, Schwartz L, Ricci S, Amadori D, Santoro A, Figer A, De Greve J, Douillard J-Y, Lathia C, Schwartz B, Taylor I, Moscovici M and Saltz LB: Phase II study of sorafenib in patients with advanced hepatocellular carcinoma. J Clin Oncol 24: 4293-4300, 2006

$7 \mathrm{Yu}$ MC and Yuan JM: Environmental factors and risk for hepatocellular carcinoma. Gastroenterology 127: S72-78, 2004.

8 Cusnir M and Patt YZ: Novel systemic therapy options for hepatocellular carcinoma. Cancer J 10: 97-103, 2004.

9 El-Serag HB and Rudolph KL: Hepatocellular carcinoma: epidemiology and molecular carcinogenesis. Gastroenterology 132: 2557-2576, 2007.

10 Poon RTP, Fan ST and Wong J: Risk factors, prevention, and management of postoperative recurrence after resection of hepatocellular carcinoma. Ann Surg 232: 10-24, 2000.

11 Nakashima O and Kojiro M: Recurrence of hepatocellular carcinoma: multicentric occurrence or intrahepatic metastasis? A viewpoint in terms of pathology. J Hepato-bil-pancr Surg 8: 404-409, 2001.

12 Nomoto S, Yamashita K, Koshikawa K, Nakao A and Sidransky D: Mitochondrial D-loop mutations as clonal markers in multicentric hepatocellular carcinoma and plasma. Clin Cancer Res 8: 481-487, 2002.

13 Nomoto S, Kinoshita T, Kato K, Otani S, Kasuya H, Takeda S, Kanazumi N, Sugimoto H and Nakao A: Hypermethylation of multiple genes as clonal markers in multicentric hepatocellular carcinoma. Br J Cancer 97: 1260-1265, 2007.

14 Nomoto S, Hishida M, Inokawa Y, Takano N, Kanda M, Nishikawa Y, Fujii T, Koike M, Sugimoto H and Kodera Y: Expression analysis of THOP1 in background liver, a prognostic predictive factor in hepatocellular carcinoma, extracted by multiarray analysis. Ann Surg Oncol 21(Suppl 3): 443-450, 2014.
15 Hlavanda E, Kovacs J, Olah J, Orosz F, Medzihradszky KF and Ovadi J: Brain-specific p25 protein binds to tubulin and microtubules and induces aberrant microtubule assemblies at substoichiometric concentrations. Biochemistry 41: 8657-8664, 2002.

16 Stangegaard M: Gene expression analysis using agilent DNA microarrays. Meth Mol Biol 529: 133-145, 2009.

17 Bibikova $M$ and Fan JB: GoldenGate assay for DNA methylation profiling. Meth Mol Biol 507: 149-163, 2009.

18 Okamura Y, Nomoto S, Hayashi M, Hishida M, Nishikawa Y, Yamada S, Fujii T, Sugimoto H, Takeda S, Kodera Y and Nakao A: Identification of the bleomycin hydrolase gene as a methylated tumor suppressor gene in hepatocellular carcinoma using a novel triple-combination array method. Cancer Lett 312: 150-157, 2011.

19 Takai D and Jones PA: The CpG island searcher: a new WWW resource. In Silico Biol 3: 235-240, 2003.

20 Forner A, Llovet JM and Bruix J: Hepatocellular carcinoma. Lancet 379: 1245-1255, 2012.

21 Imamura H, Matsuyama Y, Tanaka E, Ohkubo T, Hasegawa K, Miyagawa S, Sugawara Y, Minagawa M, Takayama T, Kawasaki $\mathrm{S}$ and Makuuchi M: Risk factors contributing to early and late phase intrahepatic recurrence of hepatocellular carcinoma after hepatectomy. J Hepatol 38: 200-207, 2003.

22 Senthilnathan S, Memon K, Lewandowski RJ, Kulik L, Mulcahy MF, Riaz A, Miller FH, Yaghmai V, Nikolaidis P, Wang E, Baker T, Abecassis M, Benson AB, 3rd, Omary RA and Salem R: Extrahepatic metastases occur in a minority of hepatocellular carcinoma patients treated with locoregional therapies: analyzing patterns of progression in 285 patients. Hepatology 55: 1432-1442, 2012.

23 Takahashi M, Tomizawa K, Ishiguro K, Sato K, Omori A, Sato S, Shiratsuchi A, Uchida T and Imahori K: A novel brain-specific 25 $\mathrm{kDa}$ protein (p25) is phosphorylated by a Ser/Thr-Pro kinase (TPK II) from tau protein kinase fractions. FEBS Lett 289: 37-43, 1991.

24 Preusser M, Lehotzky A, Budka H, Ovadi J and Kovacs GG: $\mathrm{TPPP} / \mathrm{p} 25$ in brain tumours: expression in non-neoplastic oligodendrocytes but not in oligodendroglioma cells. Acta Neuropathologica 113: 213-215, 2007.

25 Yamamoto Y, Chochi Y, Matsuyama H, Eguchi S, Kawauchi S, Furuya T, Oga A, Kang JJ, Naito K and Sasaki K: Gain of 5 p15.33 is associated with progression of bladder cancer. Oncology 72: 132-138, 2007.

26 Kang JU, Koo SH, Kwon KC, Park JW and Kim JM: Gain at chromosomal region $5 \mathrm{p} 15.33$, containing TERT, is the most frequent genetic event in early stages of non-small cell lung cancer. Cancer Genet Cytogenet 182: 1-11, 2008.

27 Safran M, Dalah I, Alexander J, Rosen N, Iny Stein T, Shmoish M, Nativ N, Bahir I, Doniger T, Krug H, Sirota-Madi A, Olender T, Golan Y, Stelzer G, Harel A and Lancet D: GeneCards Version 3: the human gene integrator. Database 2010:baq020, 2010.

28 Schofield AV, Gamell C, Suryadinata R, Sarcevic B and Bernard O: Tubulin Polymerization-promoting protein 1 (TPPP1) phosphorylation by rho-associated coiled-coil kinase (ROCK) and cyclin-dependent kinase 1 (CDK1) inhibits microtubule dynamics to increase cell proliferation. J Biol Chem 288: 7907-7917, 2013.

29 Lehotzky A, Lau P, Tokeso N, Muja N, Hudson LD and Ovadv J: Tubulin Polymerization-promoting protein (TPPP/p25) is critical for oligodendrocyte differentiation. Glia 58: 157-168, 2010.

Received July 15, 2016

Revised August 2, 2016

Accepted August 4, 2016 